\title{
Stability indicating method development and validation for simultaneous estimation of atorvastatin calcium and celecoxib in bulk and niosomal formulation by RP-HPLC
}

\author{
Priyanka S. Jadhav, Priti M. Jamkar, Amelia M. Avachat* \\ Department of Pharmaceutics, STES's Sinhgad College of Pharmacy, Maharashtra, India
}

\begin{abstract}
The present work describes development and validation of a specific, sensitive, precise and stabilityindicating high-performance liquid chromatographic method of analysis of atorvastatin calcium and celecoxib, both as a bulk drug and in niosomal formulation. The analysis has been performed by using Cosmosil-C18 column $(4.6 \mathrm{~mm} \times 250 \mathrm{~mm}, 5 \mu)$ at $25{ }^{\circ} \mathrm{C}$ using acetonitrile: ammonium acetate buffer $\mathrm{pH} 5.0$ : methanol $(50: 25: 25 \mathrm{v} / \mathrm{v} / \mathrm{v})$ as mobile phase. The detection was carried out at $277 \mathrm{~nm}$ with a flow rate of $1.0 \mathrm{~mL} / \mathrm{min}$. The retention times of Atorvastatin calcium and Celecoxib were 6.195 and $3.989 \mathrm{~min}$, respectively. The method was validated according to ICH guidelines, for specificity, precision, linearity, accuracy and robustness. Atorvastatin calcium and Celecoxib were subjected to stress conditions of hydrolysis, oxidation, photolysis and thermal degradation. The degradation was observed in oxidation and acid hydrolysis. The linearity for atorvastatin calcium and celecoxib were in the range of 100-500 $\mu \mathrm{g} / \mathrm{mL}$. The recovery study of atorvastatin and celecoxib were found to be in the range of $98.96-$ $99.92 \%$ and $98.90-100 \%$, respectively. The proposed method was validated and successfully applied to the estimation of Atorvastatin calcium and Celecoxib in combined in-house niosomal formulation.
\end{abstract}

Uniterms: Atorvastatin calcium/determination. Celecoxib/determination. High performance liquid chromatography/quality control. Niosomal formulation/quality control. Pharmaceutical formulations/ quality control.

O presente trabalho descreve o desenvolvimento e a validação de método de análise por cromatografia de alta eficiência específico, sensível, preciso e indicador de estabilidade de atorvastatina cálcica e celecoxibe, ambos como fármaco e como formulação niosômica. A análise foi realizada utilizando coluna Cosmosil-C18 $(4,6 \mathrm{~mm} \times 250 \mathrm{~mm}, 5 \mu)$ a $25^{\circ} \mathrm{C}$, e acetonitrila: tampão acetato de amônio pH 5,0: metanol $(50: 25: 25 \mathrm{v} / \mathrm{v} / \mathrm{v})$ como fase móvel. A detecção foi realizada a $277 \mathrm{~nm}$, com fluxo de $1,0 \mathrm{~mL} / \mathrm{min}$. Os tempos de retenção de atorvastatina cálcica e de celecoxibe foram 6,195 e 3,989 min, respectivamente. O método foi validado de acordo com as regras da ICH para especificidade, precisão, exatidão e robustez. A atorvastatina cálcica e o celecoxibe foram submetidos a condições de estresse por hidrólise, oxidação, fotólise e degradação térmica. A degradação foi observada por oxidação e hidrólise ácida. Observou-se a linearidade da atorvastatina cálcica e do celecoxibe na faixa de 100-500 $\mu \mathrm{g} / \mathrm{mL}$. A recuperação da atorvastatina e do celecoxibe foi observada na faixa de 98,96-99,92\% e 98,90-100\%, respectivamente. O método proposto foi validado e aplicado com sucesso para a determinação de atorvastatina cálcica e celecoxibe em formulação niosômica caseira combinada.

Unitermos: Atorvastatina cálcica/determinação. Celecoxibe/determinação. Cromatografia líquida de alta eficiência/controle de qualidade Formulação de niosomal/controle de qualidade. Formulações farmacêuticas/controle de qualidade.

*Correspondence: Dr. (Mrs.) A. M. Avachat. Department of Pharmaceutics, 


\section{INTRODUCTION}

Atorvastatin calcium is $[\mathrm{R}-(\mathrm{R} *, \mathrm{R} *)]-2-(4-$ fluorophenyl)- $\beta, \delta$-dihydroxy-5-(1-methylethyl)-3-phenyl4-[(phenylamino)carbonyl]-1H-pyrrole-1-heptanoic acid, calcium salt (2:1) trihydrate [Figure1(a)] (IP, 2007). Atorvastatin is a selective, competitive inhibitor of HMGCoA reductase, the rate-limiting enzyme that converts 3-hydroxy-3-methylglutaryl-coenzyme A to mevalonate, a precursor of sterols, including cholesterol. Atorvastatin lowers plasma cholesterol and lipoprotein levels by inhibiting HMG-CoA reductase and cholesterol synthesis in the liver and by increasing the number of hepatic LDL receptors; Atorvastatin also reduces LDL production and the number of LDL particles (Narwal, et al., 2010; Moffat, c2004).

Celecoxib is $p$-[5-p-methylphenyl-3(trifluoromethyl)-1H-pyrazol-1-yl]benzene sulfonamide [Figure 1(b)] (Moffat, c2004), it is a selective cycloxygenase-2 (PTGS2/ COX2) inhibitor used for treatment of osteoarthritis and rheumatoid arthritis. It acts by reducing prostaglandin synthesis through inhibition of COX-2. Selective COX-2 inhibitors appear to provide comparable anti-inflammatory effects to conventional non-steroidal anti-inflammatory agents (NSAIDs), while avoiding serious adverse reactions, in particular, gastrointestinal toxicity observed with chronic use of NSAIDs due to COX-1(PTGS1) inhibition (Konstantinopoulos, Lehmann, 2005).

(a)

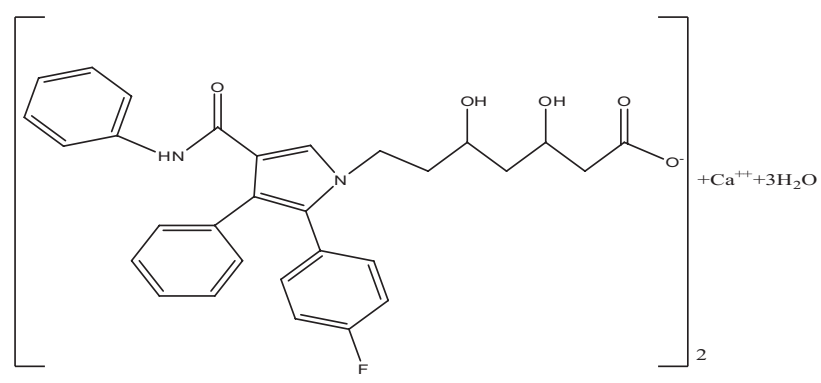

(b)

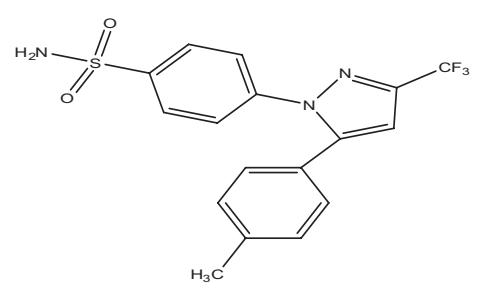

FIGURE 1 - Chemical structures of ATV Ca (a) and CXB (b).

Recent studies have indicated that in addition to the cholesterol-lowering effect, statins have pleiotropic activities that modulate other biological processes, such as cell proliferation and apoptosis. Hence, Atorvastatin acts as an anticancer agent. Celecoxib also induces the anticancer activity, the mechanism of action being that COX-2-derived PGE2 potentiates androgen biosynthesis by the cytochrome $\mathrm{P} 450$ enzyme aromatase and promotes angiogenesis, tumor maintenance/growth, and metastasis. The simultaneous inhibition of aromatase and COX-2 activity may therefore be responsible for the anticancer activity of celecoxib. Combinations of low doses of these anticancer agents i.e. Atorvastatin and celecoxib that have different mechanisms of action may together have significantly improved efficacy for inhibiting tumor formation and tumor growth when compared with individual anticancer substances alone (Xi, Xiao-Xing, Gina, 2007). However, both these drugs belongs to BCS class II and suffer from bioavalability problem (ATV Ca $14 \%$ and CXB 40\%). Niosomes are microscopic lamellar structures formed on admixture of a nonionic surfactant, cholesterol and chloroform with subsequent hydration in aqueous media. They behave in vivo like liposomes prolonging the circulation of entrapped drug and altering its organ distribution. As drug delivery vesicles, niosomes have been shown to enhance absorption of some drugs across cell membranes, to localize in targeted organs and tissues and to elude the reticuloendothelial system. Niosomes can accommodate drug molecules with a wide range of solubility and thus can show better antiangiogenic activity as compared to drugs as such (Abhinav et al., 2011; Keservani et al., 2011).

Literature survey reveals spectroscopic methods for determination of ATV as single drug or in combination with other drugs (Prajapati, Bhandari, 2011; Dey, et al., 2012). In addition, some HPLC, HPTLC and stability indicating methods have been reported for estimation of ATV in pharmaceutical dosage forms (Surekha, Swamy, Kumar, 2012; Krishnan et al., 2011; Kumar, Ghosh, Chaudhary, 2012; Mhaske, et al., 2012). CXB has been determined by UV-spectrophotometric, by HPLC and stability indicating methods (Revathi, et al., 2011; Jadhav, Gowekar, Gowekar, 2012; Baboota, et al., 2007). Plasma determination of $\mathrm{CXB}$ has also been reported (Emami, Fallah, Ajami, 2008). Various spectrophotometric and HPLC methods are reported for determination of atorvastatin and $\mathrm{CXB}$ alone and in combination with otherdrugs (Ahmed, Manohara, Ravi, 2012; Vijayamirtharaj et al., 2010). However, no Reverse phase (RP)-HPLC method has been reported so far for simultaneous estimation of ATV Ca and CXB. The aim of the present work was to develop simple, precise, accurate and reproducible RP-HPLC method for simultaneous determination of this binary drug 
formulation. The proposed method was optimized and validated in accordance with International Conference on Harmonization (ICH) guidelines (ICH, 2005).

\section{EXPERIMENTAL}

\section{Chemicals and reagents}

Pure samples of ATV Ca (Batch No. 121704002) and CXB (Batch No. 121983002) were provided as a gift sample by Lupin Research Park, Pune, India. Niosomes prepared by using span 60 , cholesterol and cholroform. All the chemicals and reagents used were of HPLC grade and purchased from Loba chemie Pvt. Ltd., Mumbai, India.

\section{Instrument}

The development and validation of the method was performed on a Shimadzu (LC 2010 CHT, Kyoto, Japan) having quaternary system with automatic injection facility. The detector consists of a UV-Vis model and was operated at $277 \mathrm{~nm}$. The software used was 'LC Solution'. The column used was Cosmosil C18 column $(4.6 \mathrm{~mm} \times 250$ $\mathrm{mm}, 5 \mu)$. Shimadzu (UV-1800, Japan) double beam spectrophotometer with two identical quartz cells was used for absorbance measurement.

\section{Methods}

\section{Preparation of In house niosomes}

Niosomal Formulation was optimized acc. to type of surfactant and method of preparation. The best surfactant was found to be span 60 among Span 20, Span 60 , Span 80 and similarly better result were obtained with ether injectiom method over Hand shaking and sonication methods. Further optimization was done w.r.t concentration of span 60 . The optimized formulation prepared by ether injection method containing Span 60:cholesterol: drug in 1:1:1(w/w/w) concentation (i.e $50 \mathrm{mg}$ Span 60, $50 \mathrm{mg}$ cholesterol, $25 \mathrm{mg}$ ATV $\mathrm{Ca}+25 \mathrm{mg}$ CXB) was used for chromatographic evaluation.

\section{Chromatographic conditions}

Chromatographic separation was achieved at $250{ }^{\circ} \mathrm{C}$ and the detection was carried at $277 \mathrm{~nm}$ at a flow rate of $1 \mathrm{~mL} / \mathrm{min}$. Run time was kept at $10 \mathrm{~min}$. Prior to the injection of drug solution, column was equilibrated for $60 \mathrm{~min}$ with the mobile phase flowing through the system. The injection volume was $20 \mu \mathrm{L}$ for assay level. The analysis was performed by using Cosmosil C18 ( $4.6 \mathrm{~mm} \times 250 \mathrm{~mm}$, packed with $5 \mu \mathrm{m}$ particle size) and the mobile phase consisting of acetonitrile: ammonium acetate buffer $\mathrm{pH}$ 5.0: methanol (55: 20:25v/v/v).

\section{Standard preparation}

The standard stock solutions: $1000 \mu \mathrm{g} / \mathrm{mL}$ of ATV $\mathrm{Ca}$ and $\mathrm{CXB}$ were prepared separately by dissolving working standards in methanol and diluting with the same solvent. Standard calibration solutions of ATV Ca and CXB having concentrations in the range of $100-500 \mu \mathrm{g} /$ $\mathrm{mL}$ were prepared separately by diluting stock solutions with methanol. A representative chromatogram of standard preparation is shown in Figure 2.

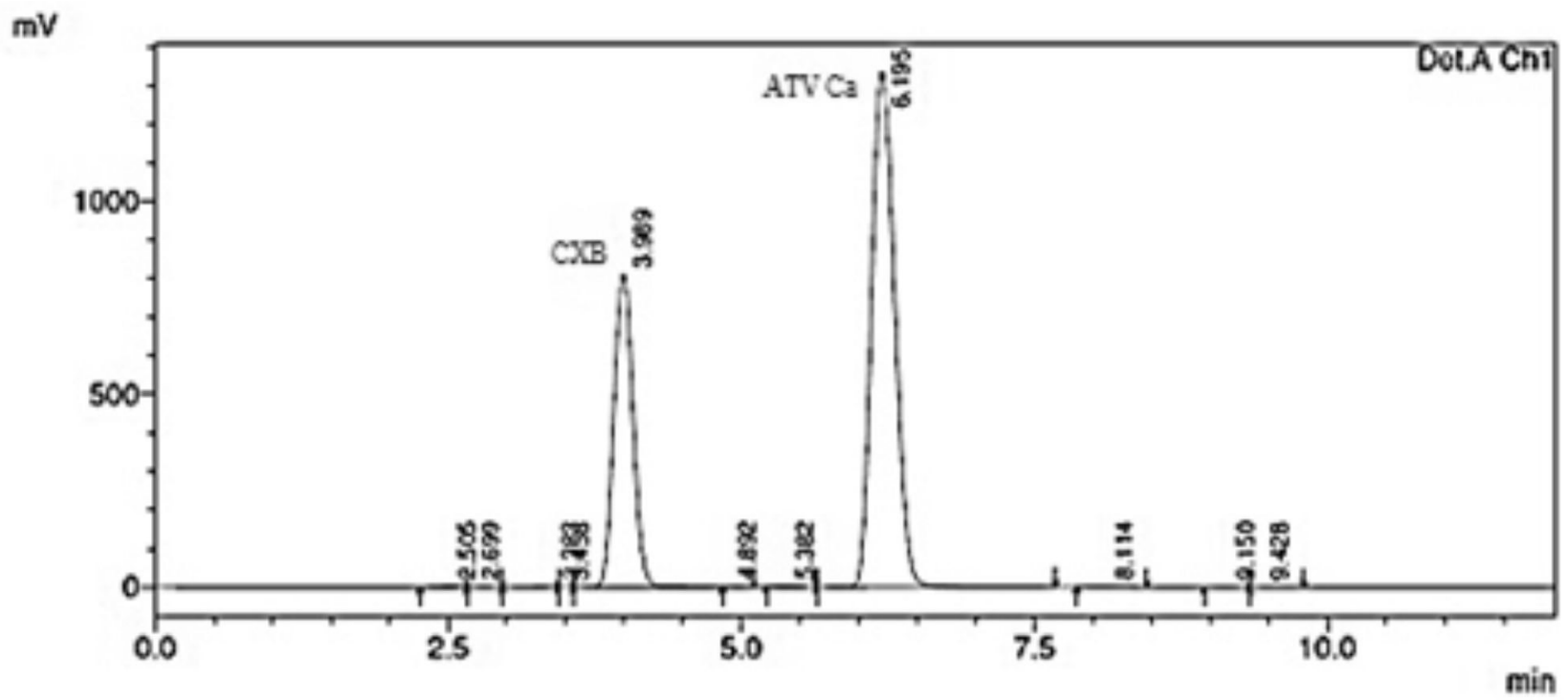

FIGURE 2 - Chromatogram of standard preparation of ATV Ca and CXB. 


\section{Sample solution}

In house niosomal formulation of $50 \mathrm{mLwas}$ prepared containing $25 \mathrm{mg}$ ATV Ca and $25 \mathrm{mg}$ CXB in combination. Sample of niosomal formulation equivalent to $5 \mathrm{mg}$ of ATV Ca and CXB was accurately weighed and transferred into $10 \mathrm{~mL}$ volumetric flask and then diluted with methanol. The contents were sonicated for 15 minutes with intermittent shaking. This solution was filtered through $0.45 \mu \mathrm{m}$ nylon filter, discarding first three $\mathrm{mL}$ of filtrate. Representative chromatogram of sample preparation is shown in Figure 3.

\section{Analytical method validation}

\section{System suitability parameters}

Mixed standard solution of ATV $\mathrm{Ca}$ and CXB was injected into the system for five times and system suitability parameters (tailing factor, retention time and theoretical plates) were checked.

\section{Specificity}

To assess the method specificity, blank and placebo solutions were injected into the HPLC system using the test conditions as specified above. The chromatogram was recorded and the responses of the peaks if any measured.

\section{Linearity}

The linearity of method was obtained by preparation of the calibration curve in 6 replicates. The calibration curve for ATV $\mathrm{Ca}$ and $\mathrm{CXB}$ was obtained by plotting separately the peak area of ATV Ca and CXB versus concentration of ATV Ca and CXB over the range of 100 $500 \mu \mathrm{g} / \mathrm{mL}$.

\section{Accuracy}

The recovery experiments were performed by adding a known quantity of pure standard drug into the solution of the tablet powder. The sample was then spiked with standard at levels $80 \%, 100 \%$ and $120 \%$ of test concentration. The resulting spiked sample solutions were assayed in triplicate.

\section{Precision}

The precision of an analytical procedure expresses the closeness of agreement (degree of scatter) between a series of measurements obtained from multiple sampling of the same homogeneous sample under the prescribed conditions. Repeatability of standard application (System precision) and inter day precision study of ATV Ca and CXB were carried out by estimating the corresponding responses on the same day and on next day for 3 different concentrations of ATV Ca and CXB (200, 300, $400 \mu \mathrm{g} /$ $\mathrm{mL}$ ) in triplicate. Repeatability expresses the precision under the same operating conditions over a short interval of time. Repeatability is also termed intra-assay precision.

\section{Robustness}

Robustness of the method was determined by analyzing standard solutions at normal operating conditions and by changing some operating analytical conditions such as flow rate $(0.8,1.0$ and $1.2 \mathrm{~mL} / \mathrm{min})$, mobile phase ratio $(52: 23: 25,50: 25: 25$ and $48: 27: 25$ $\mathrm{v} / \mathrm{v} / \mathrm{v})$, and detection wavelength $(275,277$ and $279 \mathrm{~nm})$.

\section{$L O D \& L O Q$}

Six sets of Calibration curve were prepared and LOD and LOQ were calculated by using the formula:

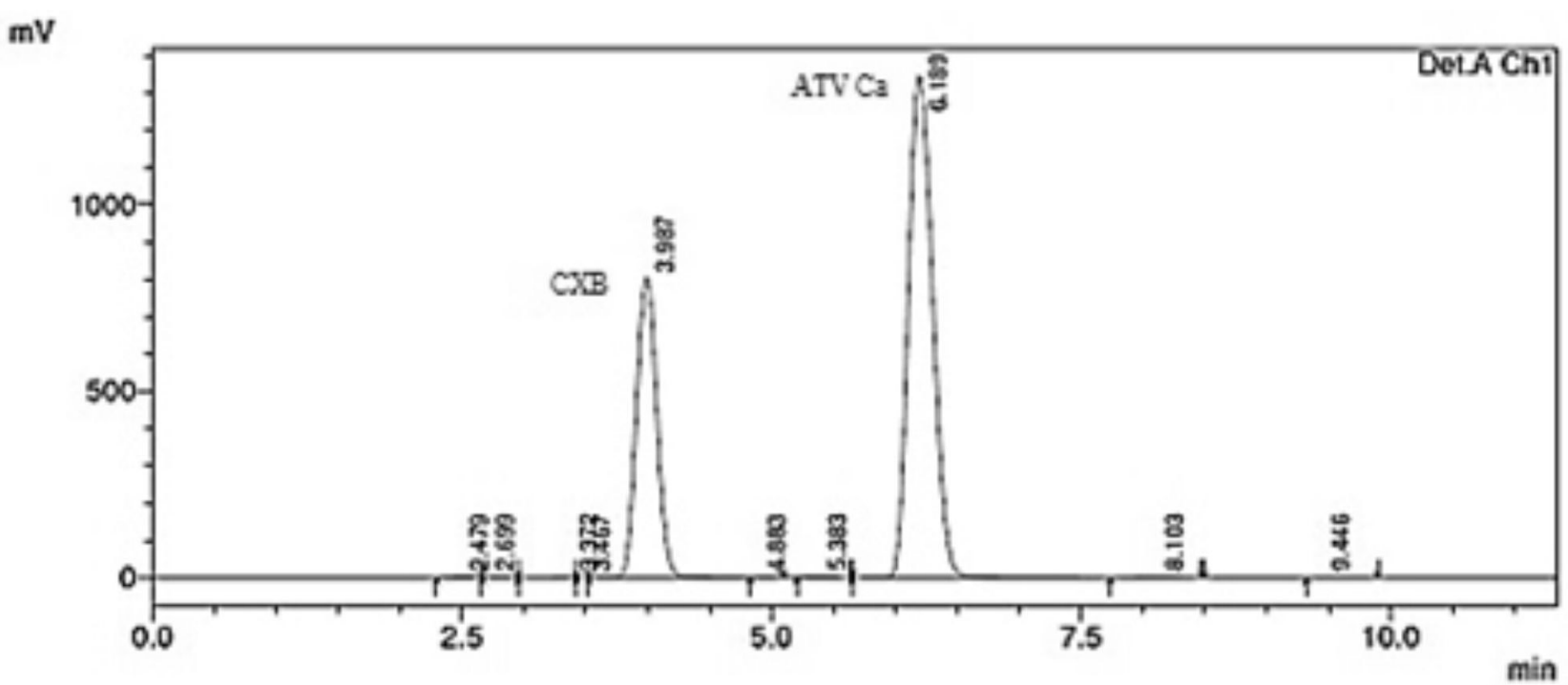

FIGURE 3 - Chromatogram of sample preparation of ATV Ca and CXB. 


$$
L O D=3.3 \frac{S D}{S} \quad L O Q=10 \frac{S D}{S}
$$

where SD is standard deviation of y-intercept of the calibration curves; $\mathrm{S}$ is mean slope of six calibration curves.

\section{Forced Degradation Studies}

ATV Ca and CXB standard samples were degraded under different stress conditions like acidic, alkali, oxidative hydrolysis and dry heat conditions. For acid and base degradation, samples were refluxed with $1 \mathrm{M} \mathrm{HCl}$ and $1 \mathrm{M} \mathrm{NaOH}$ at $70{ }^{\circ} \mathrm{C}$ for $3 \mathrm{~h}$. For oxidation, $30 \% \mathrm{v} / \mathrm{v} \mathrm{H}_{2} \mathrm{O}_{2}$ was refluxed at $70{ }^{\circ} \mathrm{C}$ for $3 \mathrm{~h}$. For thermal degradation, sample was exposed to heat in oven at $100{ }^{\circ} \mathrm{C}$ for $6 \mathrm{~h}$ and for photo degradation; drug was exposed to direct sunlight for $6 \mathrm{~h}$. Acid and base treated samples were neutralized and all the samples were then diluted to a concentration of $500 \mu \mathrm{g} / \mathrm{mL}$ with methanol. The samples were withdrawn and subjected to RP-HPLC analysis under optimized conditions.

\section{RESULTS AND DISCUSSION}

\section{Method}

For HPLC method optimization, different ratios of acetonitrile and ammonium acetate buffer $\mathrm{pH} 5$ were tried but resolution of peak was not achieved. So, methanol was used as third mobile phase. Different ratios of acetonitrile, Ammonium acetate buffer pH5 and methanol were tried i.e. $60: 20: 20 \mathrm{v} / \mathrm{v} / \mathrm{v}, 65: 15: 20 \mathrm{v} / \mathrm{v} / \mathrm{v}, 55: 25: 20 \mathrm{v} / \mathrm{v} / \mathrm{v}$. It was found that acetonitrile: ammonium acetate buffer: methanol in the ratio 50:25:25 v/v/v as mobile phase at a flow rate of $1.0 \mathrm{~mL} / \mathrm{min}$ gave good peaks. Thus, Cosmosil-C18 (4.6 mm $\times 250 \mathrm{~mm}, 5 \mu \mathrm{m})$ column, $1 \mathrm{~mL} /$ min flow rate, $20 \mu \mathrm{L}$ injection volume, $25^{\circ} \mathrm{C}$ column oven temperature, $277 \mathrm{~nm}$ wavelength were the conditions, which were found to be suitable for the separation of peaks. These chromatographic conditions gave a retention time of 6.195 and $3.989 \mathrm{~min}$ for ATV Ca and CXB, respectively.

\section{System suitability parameters}

System suitability parameters (tailing factor, retention time and theoretical plates) were found within acceptance criteria. Relative standard deviation (RSD) for area was found satisfactory and meeting ICH specifications $(\% \mathrm{RSD} \leq 2 \%)$. Summary of system suitability parameters is tabulated in Table I.
TABLE I - Summary of system suitability parameters

\begin{tabular}{lccc}
\hline \multirow{2}{*}{$\begin{array}{l}\text { S ystem suitability } \\
\text { parameter }\end{array}$} & \multicolumn{2}{c}{ Observations } & $\begin{array}{c}\text { Acceptance } \\
\text { criteria }\end{array}$ \\
\cline { 2 - 4 } & ATV Ca & CXB & \\
\hline Tailing factor & 1.209 & 1.089 & $\leq 2$ \\
Retention Time $\left(\mathrm{t}_{\mathrm{R}}\right)(\mathrm{min})$ & 6.195 & 3.989 & $\geq 2$ \\
Theoretical plates & 4484.450 & 2729.27 & $\geq 2000$ \\
\% RSD* of area & 0.144 & 0.356 & $\leq 2$ \\
\hline$* \mathrm{n}=5$ & & &
\end{tabular}

\section{Specificity}

Specificity of the method was checked by injecting the placebo solution; no peaks were found at the retention time of ATV $\mathrm{Ca}$ and CXB.

\section{Linearity}

A good linear relationship as indicated by correlation coefficient value 0.997 and 0.999 were observed for ATV Ca and CXB, respectively over the range of 100$500 \mu \mathrm{g} / \mathrm{mL}$. The slope and intercept value for calibration curve was found as; $y=16398 x+18575$ for ATV Ca and $y=9235 x+30017$ for CXB. The results of linearity are tabulated in Table II.

TABLE II - Results of linearity

\begin{tabular}{lcc}
\hline Parameter & ATV Ca & CXB \\
\hline $\begin{array}{l}\text { Linearity range } \\
(\mu \mathrm{g} / \mathrm{mL})\end{array}$ & $100-500$ & $100-500$ \\
$\mathrm{r}^{2} \pm \mathrm{SD}^{*}$ & $0.997 \pm 0.0005$ & $0.999 \pm 0.0057$ \\
Slope $\pm \mathrm{SD}^{*}$ & $16206 \pm 23.51$ & $9099.8 \pm 26.52$ \\
Intercept $\pm \mathrm{SD}^{*}$ & $360880 \pm 5643.49$ & $45259.33 \pm 2738.38$ \\
$\mathrm{LOD}(\mu \mathrm{g} / \mathrm{mL})$ & 1.149176 & 0.993063 \\
$\mathrm{LOQ}(\mu \mathrm{g} / \mathrm{mL})$ & 3.482351 & 3.009282 \\
\hline$*_{\mathrm{n}=6}$ & &
\end{tabular}

\section{Accuracy}

The accuracy of the method was determined by recovery studies and the percentage recovery was calculated. The recoveries of ATV Ca and CXB were found to be in the range of $98.96-99.92 \%$ and $98.90-100 \%$, respectively. The results were compared with the expected results and expressed as percentage as given in Table III.

\section{Precision}

The precision of the method is satisfactory as \% RSD is not more than $2 \%$. The results of the precision study are given in Table IV. 

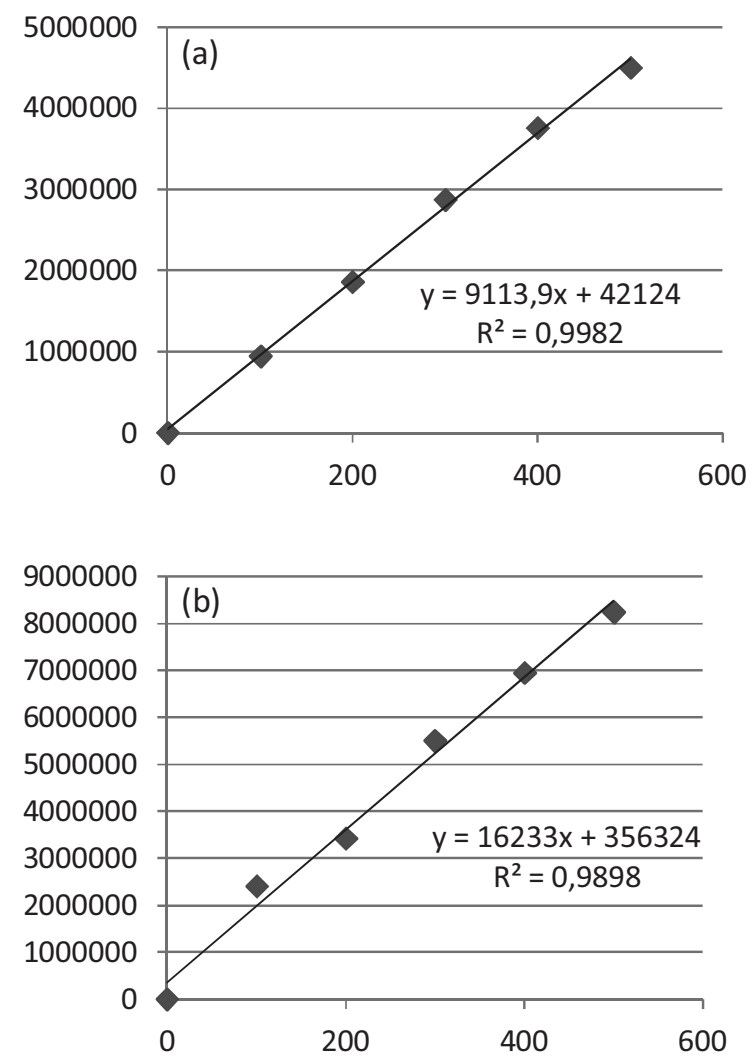

FIGURE 4 - (a) Linearity of CXB ; (b) Linearity of ATV Ca.

\section{Robustness}

The results for robustness of the method are given in Table V; the results obtained were satisfactory as $\% \mathrm{RSD}$ found to be less than $2 \%$. The parameters like tailing factor and retention times showed adherence to the limits.

\section{$\angle O D$ and $L O Q$}

Results of LOD and LOQ are tabulated in Table II.

\section{Analysis of In-house niosomal formulation}

The proposed liquid chromatographic method was applied to the determination of ATV Ca and CXB in their combined dosage forms (In-house prepared niosomal formulation). The results for ATV $\mathrm{Ca}$ and $\mathrm{CXB}$ were comparable with the corresponding added/labeled amounts given in Table VI.

\section{Forced degradation study}

The drugs were degraded under acidic and oxidative condition while they were stable in alkaline, photolytic and thermal conditions. The ATV Ca gets degraded to form the lactone compound while the degradation product of $\mathrm{CXB}$ is unknown (Shah, Kumar, Singh, 2008). The chromatogram of forced degradation studies is given in Figure 5 and the results of stability studies are given in Table VII.

TABLE III - Results of Accuracy study

\begin{tabular}{lcccc}
\hline Drug & Level & $\begin{array}{c}\text { Theoretical Amount }(\mu \mathrm{g} / \\
\mathrm{mL})\end{array}$ & Mean \% Recovery & \% RSD* \\
\hline \multirow{3}{*}{ ATV Ca } & $50 \%$ & 150 & 98.75 & 0.34 \\
& $100 \%$ & 300 & 98.25 & 0.39 \\
& $150 \%$ & 450 & 99.81 & 0.57 \\
\hline \multirow{2}{*}{ CXB } & $50 \%$ & 150 & 99.44 & 0.45 \\
& $100 \%$ & 300 & 97.56 & 0.81 \\
\hline
\end{tabular}

$*_{n}=3$

TABLE IV - Results of precision study

\begin{tabular}{lccc}
\hline Drug & Concentration $(\mu \mathrm{g} / \mathrm{mL})$ & Inter-day $(\%$ RSD & Repeatability $\left(\%\right.$ RSD $\left.^{*}\right)$ \\
\hline \multirow{2}{*}{ ATV Ca } & 200 & 0.125 & 0.132 \\
& 300 & 0.178 & 0.183 \\
& 400 & 0.171 & 0.179 \\
CXB & 200 & 0.07 & 0.05 \\
& 300 & 0.04 & 0.08 \\
\hline
\end{tabular}


TABLE V - Results of robustness studies

\begin{tabular}{|c|c|c|c|c|c|c|c|}
\hline \multicolumn{4}{|c|}{$\begin{array}{l}\text { Robustness study of ATV Ca } \\
\text { Chromatographic changes }\end{array}$} & \multicolumn{4}{|c|}{$\begin{array}{l}\text { Robustness study of CXB } \\
\text { Chromatographic changes }\end{array}$} \\
\hline Factor & Level & $\begin{array}{l}\text { Retention time } \\
\left(t_{R}\right)(\min )\end{array}$ & Area & Factor & Level & $\begin{array}{l}\text { Retention time } \\
\left(t_{R}\right)(\min )\end{array}$ & Area \\
\hline \multicolumn{4}{|c|}{ Flow rate $(\mathrm{mL} / \mathrm{min})$} & \multicolumn{4}{|c|}{ Flow rate $(\mathrm{mL} / \mathrm{min})$} \\
\hline 0.8 & -0.2 & 6.172 & 13044484 & 0.8 & -0.2 & 3.995 & 7350366 \\
\hline 1.0 & 0 & 6.12 & 12666143 & 1.0 & 0 & 3.985 & 7196852 \\
\hline 1.2 & 0.2 & 6.173 & 12933150 & 1.2 & 0.2 & 3.993 & 7255729 \\
\hline \multicolumn{2}{|c|}{$\% \mathrm{RSD}^{*}$} & 0.4925 & 1.5094 & \multicolumn{2}{|c|}{$\% \mathrm{RSD}^{*}$} & 0.1325 & 1.0656 \\
\hline \multicolumn{4}{|c|}{$\begin{array}{c}\text { Ratio of Mobile phase } \\
\text { (ACN: Ammonium acetate buffer pH 5.0: Methanol) }\end{array}$} & \multicolumn{4}{|c|}{$\begin{array}{c}\text { Ratio of Mobile phase } \\
\text { (ACN: Ammonium acetate buffer pH 5.0: Methanol) }\end{array}$} \\
\hline $52: 23: 25$ & -2 & 6.119 & 12670019 & $52: 23: 25$ & -2 & 3.982 & 7196852 \\
\hline $50: 25: 25$ & 0 & 6.12 & 12666143 & $50: 25: 25$ & 0 & 3.985 & 7196852 \\
\hline $48: 27: 25$ & 2 & 6.166 & 12924476 & $48: 27: 25$ & 2 & 3.994 & 7330361 \\
\hline \multicolumn{2}{|c|}{$\% \mathrm{RSD}^{*}$} & 0.4376 & 1.1607 & \multicolumn{2}{|c|}{$\% \mathrm{RSD}^{*}$} & 0.1566 & 1.0644 \\
\hline \multicolumn{4}{|c|}{ Wavelength (nm) } & \multicolumn{4}{|c|}{ Wavelength (nm) } \\
\hline 275 & -2 & 6.08 & 12449856 & 275 & -2 & 3.961 & 7217802 \\
\hline 277 & 0 & 6.12 & 12666143 & 277 & 0 & 3.985 & 7196852 \\
\hline \multirow[t]{2}{*}{279} & 2 & 6.104 & 12758710 & 279 & 2 & 3.98 & 6983030 \\
\hline & & 0.3299 & 1.2554 & \multicolumn{2}{|c|}{$\% \mathrm{RSD}^{*}$} & 0.3185 & 1.8215 \\
\hline
\end{tabular}

$* \mathrm{n}=3$

TABLE VI - Result of analysis of In-house niosomal formulation by proposed RP-HPLC method

\begin{tabular}{lcc}
\hline Parameters & ATV Ca & CXB \\
\hline Label Claim $(\mathrm{mg})$ & 25 & 25 \\
Actual content found* $(\mathrm{mg})$ & $24.78 \pm 0.78$ & $24.82 \pm 0.08$ \\
\% Recovery & 99.12 & 99.28 \\
\% RSD* & $0.53 \%$ & $0.8 \%$ \\
$*_{\mathrm{n}=3}$ & &
\end{tabular}

TABLE VII - Degradation studies of ATV Ca and CXB by HPLC

\section{CONCLUSIONS}

The HPLC method developed for the analysis of mixture of ATV Ca and CXB in their pharmaceutical preparations is stability indicating, precise, accurate and with a short run time. The method was fully validated showing satisfactory data for all the method validation parameters tested. The developed method can be conveniently applied for the routine estimation of ATV $\mathrm{Ca}$ and $\mathrm{CXB}$.

\begin{tabular}{lccccc}
\hline Stress condition & $\begin{array}{c}\text { Amount of ATV Ca Amount of ATV Ca } \\
\text { degraded (\%) }\end{array}$ & $\begin{array}{c}\text { Amount of CXB } \\
\text { recovered (\%) }\end{array}$ & $\begin{array}{c}\text { Amount of CXB } \\
\text { degraded (\%) }\end{array}$ & $\begin{array}{c}\mathrm{t}_{\mathrm{R}} \text { of degraded } \\
\text { products (min) }\end{array}$ \\
\hline $1 \mathrm{M} \mathrm{HCl}\left(3 \mathrm{~h}\right.$ at $\left.70{ }^{\circ} \mathrm{C}\right)$ & 11.19 & 88.80 & 4.29 & 95.70 & 4.933 \\
$1 \mathrm{M} \mathrm{NaOH}\left(3 \mathrm{~h}\right.$ at $\left.70^{\circ} \mathrm{C}\right)$ & 0.039 & 99.96 & 0.12 & 99.87 & - \\
$\mathrm{H}_{2} \mathrm{O}_{2}\left(3 \mathrm{~h}\right.$ at $\left.70^{\circ} \mathrm{C}\right)$ & 28.81 & 71.18 & 14.89 & 85.10 & $1.156,8.376$ \\
Dry heat $\left(6 \mathrm{~h}\right.$ at $\left.100^{\circ} \mathrm{C}\right)$ & 2.52 & 97.47 & 0.076 & 99.92 & - \\
Sunlight $(6 \mathrm{~h})$ & 2.18 & 97.81 & 0.094 & 99.90 & - \\
\hline
\end{tabular}

$\mathrm{t}_{\mathrm{R}}=$ Retention time, $-=$ no degradation 

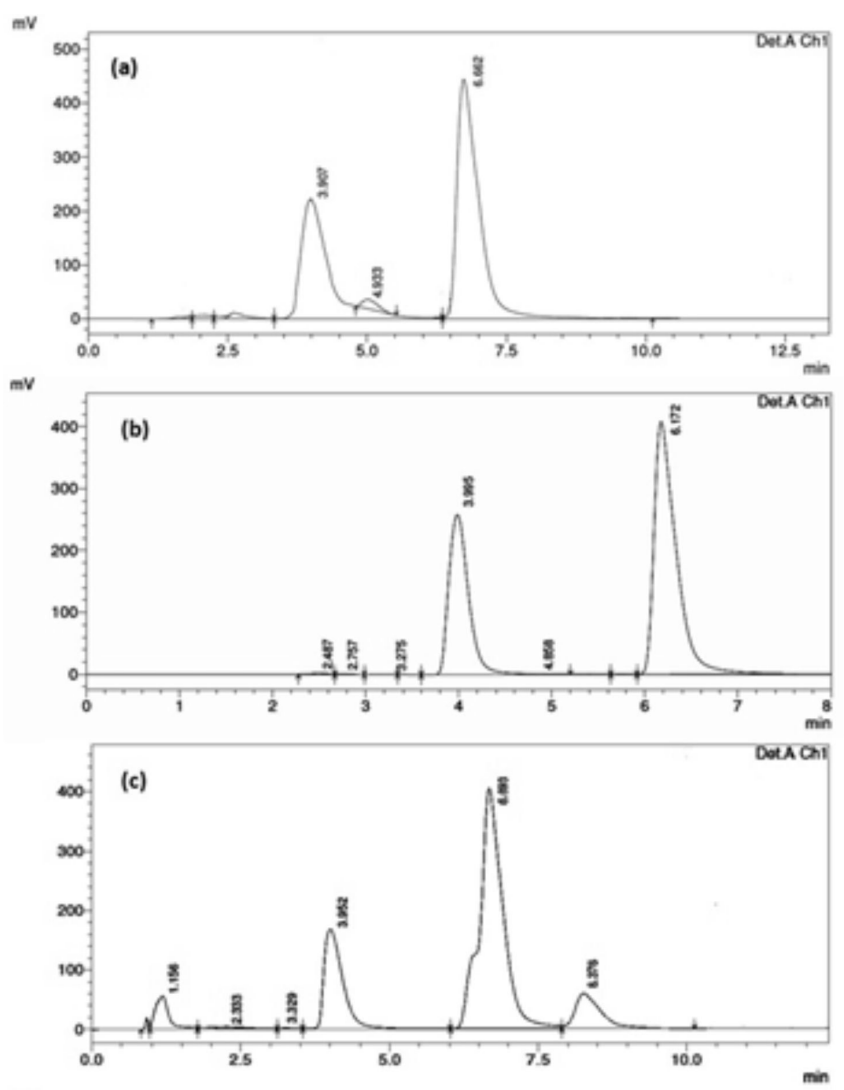

$m v$

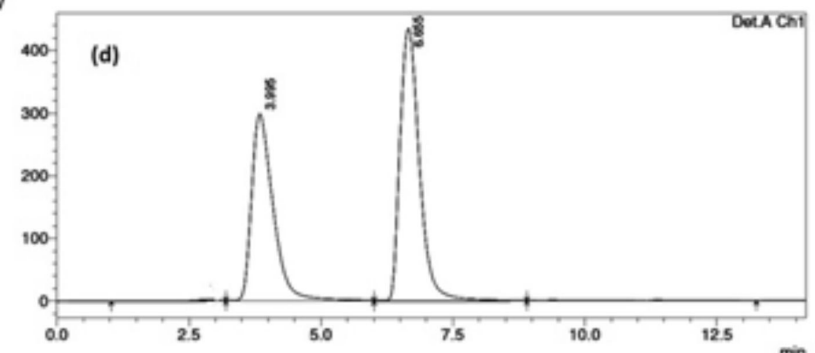

$m v$

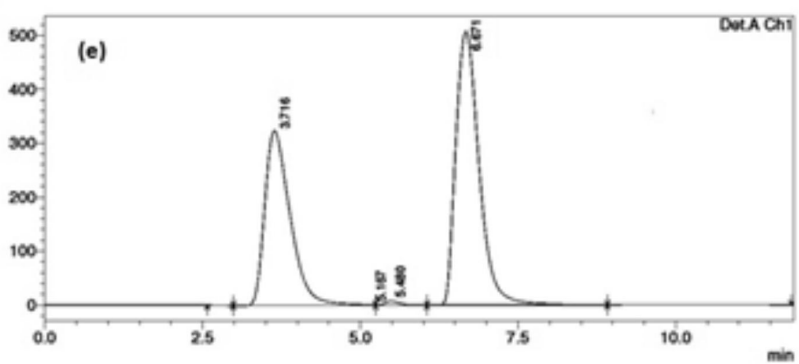

FIGURE 5 - HPLC chromatogram of (a)acid (1M HCl, $3 \mathrm{~h}$ at $70{ }^{\circ} \mathrm{C}$ ) treated ATV Ca; $t_{\mathrm{R}} 6.662$ and $\mathrm{CXB} ; \mathrm{t}_{\mathrm{R}} 3.907$, degradation product (D1); $\mathrm{t}_{\mathrm{R}} 4.933$. (b)Alkali $\left(1 \mathrm{M} \mathrm{NaOH}, 3 \mathrm{~h}\right.$ at $\left.70{ }^{\circ} \mathrm{C}\right)$ treated ATV Ca; $t_{R} 6.172$ and $\mathrm{CXB} ; \mathrm{t}_{\mathrm{R}} 3.995$ (c) $\mathrm{H}_{2} \mathrm{O}_{2}(30 \%$ $\mathrm{H}_{2} \mathrm{O}_{2}, 3 \mathrm{~h}$ at $70{ }^{\circ} \mathrm{C}$ ) treated ATV Ca; $\mathrm{t}_{\mathrm{R}} 6.693$ and CXB; $\mathrm{t}_{\mathrm{R}} 3.952$, degradation products (D1); $\mathrm{t}_{\mathrm{R}} 1.156,(\mathrm{D} 2) ; \mathrm{t}_{\mathrm{R}} 8.376$ (d) Heat (6 $\mathrm{h}$ at $100{ }^{\circ} \mathrm{C}$ treated ATV Ca; $t_{\mathrm{R}} 6.665$ and $\mathrm{CXB} ; \mathrm{t}_{\mathrm{R}} 3.995$ (e) Sunlight ( 6 hr.) treated of ATV Ca; $\mathrm{t}_{\mathrm{R}} 6.671$ and $\mathrm{CXB} ; \mathrm{t}_{\mathrm{R}} 3.716$.

\section{ACKNOWLEDGEMENTS}

The authors would like to acknowledge Lupin Research Park, Pune, (India) for providing API of ATV $\mathrm{Ca}$ and $\mathrm{CXB}$ as gift samples.

\section{REFERENCES}

ABHINAV, K.; LAL, P.; JAISWAL, A.; SINGH V. Review on niosomes as novel drug delivery system. Int. Res. J. of Pharm., v.2, n.5, p. 61-65, 2011.

AHMED, M.; MANOHARA, Y.N.; RAVI, M.C. RP-HPLC method development and validation for simultaneous estimation of atorvastatin calcium and amlodipine besylate. Int. J. Chem. Tech. Res., v.4, n.1, p.337-345, 2012.

BABOOTA, S.; FAIYAZ, S.; AHUJA, A.; ALI, J.; SHAFIQ, S.; AHMAD, S. Development and validation of a stabilityindicating HPLC method for analysis of celecoxib (Cxb) in bulk drug and microemulsion formulations. Acta Chromatogr., v.18, p.116-129, 2007.

DEY, S.; SARKAR, S.; MALAKAR, J.; GHOSH, A.; G A N G O PA D H Y A , A .; M A Z UM DER, B. Spectrophotometric method for simultaneous determination of atenolol and atorvastatin in tablet dosage forms. Int. J. Pharm. Biomed. Res., v.3, n.1, p.40-43, 2012.

EMAMI, J.; FALLAH, R.; AJAMI, A. A rapid and sensitive HPLC method for the analysis of celecoxib in human plasma: application to pharmacokinetic studies. $D A R U$., v.16, n.4, p.211-217, 2008.

INDIAN PHARMACOPOEIA COMISSION. IP. Indian Pharmacopoeia. 6.ed. New Delhi: Govt. of India; The Controller of Publication, 2007. v.2, p.131-133.

INTERNATIONAL CONFERENCE ON HARMONIZATION. $\mathrm{ICH}$, Technical requirements for registration of pharmaceutical for human use harmonized tripartite guideline. Validation of analytical procedures: text and methodology Q2(R1). London, 2005.

JADHAV, K.; GOWEKAR N.; GOWEKAR, S. A validated RP-HPLC method for the determination of celecoxib in bulk and pharmaceutical dosage form. Int. J. Res. Pharm. Biomed. Sci.,v.3, n.3, p.1312-1316, 2012. 
KONSTANTINOPOULOS, P.; LEHMANN, D. F. The cardiovascular toxicity of selective and nonselective cyclooxygenase inhibitors: Comparisons, contrasts, and aspirin confounding. J. Clin. Pharmacol., v.45, n.7, p.742$750,2005$.

KESERVANI, R.K.; SHARMA, A.K.; AYAZ, M.; KESHARWANI, R.K. Review novel drug delivery system for the vesicular delivery of drug by the niosomes. Int. J. Res. Control. Release, v.1, n.1, p.1-8, 2011.

KRISHNAN, S.; KUMAR, P.; KUMAR, V.; SUNIL; SURENDERNATH, Y. HPLC method development of atorvastatin by RP-HPLC in its bulk dosage forms. IJRAP., v.2, n.5, p.1604-1606, 2011.

KUMAR, P.; GHOSH, A.; CHAUDHARY, M. Stability indicating method development for simultaneous estimation of ezetimibe and atorvastatin in pharmaceutical formulations by RP-HPLC. Pharm. Anal. Acta., v.3, n.6, p.1-6, 2012.

MHASKE, R.; SAHASRABUDHE, S.; MHASKE A. A.; GAROLE, D. J. RP-HPLC method for simultataneous determination of atorvastatin calcium, olmesartan medoxomil, candesartan, hydrochlorothiazide and chlorthalidone-application to commercially available drug products. IJPSR., v.3, n.3, p.793-801, 2012.

MOFFAT, A.C. (org). Clarke's analysis of drugs and poisons. 3.ed. London: Pharmaceutical Press, c2004. 1248 p.

NARWAL, R.; AKHLAGHI, F.; ASBERG, A.; HERMANN, M.; ROSENBAUM, S. Development of a population pharmacokinetic model for atorvastatin acid and its lactone metabolite. Clin.Pharmacokinet., v.49, n.10, p.693-702, 2010 .
PRAJAPATI, K.; BHANDARI, A. Spectroscopic method for estimation of atorvastatin calcium in tablet dosage form. Indo Global J. Pharm. Sci., v.1, n.4, p.294-299, 2011.

REVATHI, R.; PERUMAL, R.; SUDHARSHINI, S.; ANSAR, A.; THILAGALAKSHMI, A.; DINESH, A. Simple UV spectrophotometric determination of celecoxib in pure form and in pharmaceutical formulations. Int. J. Pharm. Sci. Lett., v.1, n.2, p.49-50, 2011.

SHAH, R.; KUMAR, V.; SINGH, S. Liquid chromatography/ mass spectrometric studies on atorvastatin and its stress degradation products. Rapid Comm. Mass Spectrom., v. 22, n.5, p.613-622, 2008.

SUREKHA, M.; SWAMY, G.; KUMAR, D. Development and validation of RP-HPLC method for the estimation of atorvastatin in bulk and tablet dosage form. Int. J. Pharm. Sci.,v.2, n.4, p.91-93, 2012.

VIJAYAMIRTHARAJ, R.; RAMESH, J.; JAYALAKSHMI B.; HASHIM, H.; Development and validation of RP-HPLC method for the simultaneous estimation of telmisartan and atorvastatin calcium in tablet dosage forms. Pharm. Globale (IJCP)., v.4, p.1-4, 2010.

XI, Z., XIAO-XING, C.; GINA, A. Atorvastatin and celecoxib inhibit prostate PC-3 tumors in immunodeficient mice. Clin. Cancer Res., v.13, n.18, p.5480-5487, 2007.

Received for publicationon on $16^{\text {th }}$ September 2013 Accepted for publicationon on $02^{\text {nd }}$ September 2014 
